\title{
Through the Nature Reserves of the Soviet Union (in Russian), by A. G. Bannikov. Mysl', Moscow.
}

Professor Bannikov is probably the best known Soviet conservationist in the West, recipient of the World Wildlife Fund Gold Medal and a contributor to Oryx. In this second revised and expanded edition of his valuable handbook on Soviet nature reserves a short preface and a general introduction are followed by separate chapters on fourteen of the most interesting reserves (in which he has spent several months) with maps of the location and area of each. Finally there is a complete list with descriptions of the 101 nature reserves and the nature-cum-game reserves, divided largely into their vegetational zones. There is also a fold-out map and 30 pages of colour and black-and-white photographs.

As the author says, the eight years since the first edition have seen many changes, including 25 new reserves - the number is still increasing - and an international research programme under IBP. And the study of the different ecosystems represented in these reserves has become even more imperative in view of the rapid economic development of huge, previously untouched areas and their ecological disruption. These reserves, anything up to 3700 square miles in size, embrance a remarkable variety of rich and often rare wildlife, situated as they are in tundra, forest (ranging from boreal to monsoon), steppe, desert and mountain. Their value is immense for the study of specific fauna and flora, and they have saved from extinction such species as the kulan, Ussuri tiger, Barguzin sable and saiga antelope (on which Bannikov himself did so much work). Unfortunately few foreigners have had the privilege of seeing them, so they are all little known outside the Soviet Union.

JOHN MASSEY STEWART

British Seals, by H. R. Hewer. Collins, £3.50.

Two species of seal occupy the British seaboard. The grey seal is the larger and breeds in autumn and winter, usually in remote sites; the common seal breeds closer to human communities in summer. The grey pup is nursed on land; the common pup swims at birth. They are elusive creatures, often mistaken for each other, and have provided a challenge to research which is demanding both intellectually and physically. The name of Frank Fraser Darling is linked with the pioneer work on the grey seal. His work was cut short by the war, but he had awakened the curiosity of many and, though he never returned to the work, it was continued by others in the 1950s and 1960s. Principal among these was Professor Humphrey Hewer, who, with great personal dedication, encompassed the entire field of action in seal biology, from his laboratory bench at Imperial College to many remote rookeries such as North Rona, and also in committee.

British Seals is testimony to some twenty years of integrated effort by many, particularly the staff of the Seals Research Unit of NERC, the Northumberland and Durham Natural History Society and the Scottish NC staff, who blocked in the scientific accounts of animals in close contact with Hewer and his university colleagues. It is a monograph in the New Naturalist series with the scope and qualities of a classical zoology work. There is anatomy, physiology (especially reproduction), population structure and dynamics, behaviour, other species occasionally seen, and conservation against the background impact on fisheries. Much more is known about the grey than the common seal, but that is no fault of this first-class book; the common seal is much more of a 'will-o-the-wisp'.

Professor Hewer's death just before the book was published was a great loss to British zoology and to seal biology. However, this book, clearly and critically written and finely illustrated, will long endure as a basic reference work on the British Phocidae. 